\title{
Functional Analysis of Second-step Host Specificity Mutations in Unstable Escherichia coli Heterozygotes
}

\author{
By J. HUBÁČEK \\ Department of Bacterial Genetics, Institute of Microbiology, \\ Czechoslovak Academy of Sciences, Prague 4, Czechoslovakia
}

(Received I9 March I973; revised 30 May 1973)

\begin{abstract}
SUMMARY
From an Escherichia coli strain KI2 carrying a temperature-sensitive hostspecific modification ( $h s m$ ) mutation, second-step mutants have been isolated that are completely deficient in modification and restriction. Complementation analysis has revealed that one group of these mutants is impaired in the specificity gene hss, while in the other group of mutant strains both mutations, i.e. the first-step temperature-sensitive and the second-step which impairs restriction and modification completely, are located in hsm. Analysis of the heterozygotes used in the complementation experiments suggested a cis- and tandem arrangement of the $h s$ and leu genes in haploid, segregating exconjugants; however, the attachment of these genes to a cryptic plasmid was not excluded.
\end{abstract}

\section{INTRODUCTION}

To study the mode of interaction of the polypeptides it is necessary to establish in which of the three genes involved in restriction and modification, hss, hsr and hsm (Glover \& Colson, I969; Arber \& Linn, I969), any isolated mutation is located. Based upon a complementation analysis, genotypes for mutants temperature-sensitive (ts) in restriction and modification have been proposed (Hubáček \& Glover, I970). Second-step mutants isolated from these temperature-sensitive mutants were deficient in both restriction and modification. They were of two types: the first type contains mutations which appear to be located in the hss gene, the second type contains mutations located in the hsm gene. A crucial genetical test to support the idea that for the expression of restriction the interaction of $h s s, h s r$ and hsm gene products is required, is to demonstrate complementation for temperature-sensitive restriction and modification between these two types of mutant. This paper reports the results of such a test.

\section{METHODS}

Bacteria. Escherichia coli strains used are described in Table I.

Bacteriophages. $\lambda$ vir, phage PI and F2 male-specific phage.

Media. Bacterial and phage buffers, M9 medium, L-broth, L-amino acid supplements, thiamin and streptomycin concentrations used were as described previously (Hubáček \& Glover, I970). M9 medium and L-broth were solidified with I.5\% (w/v) Oxoid agar no. 3 . For soft agar overlays $0.6 \%$ nutrient agar or water-soft agar was used.

Tests for restriction and modification, transduction procedure, preparation of $F^{\prime}$ factors and methods for construction of $F^{\prime}$ merodiploids. These were described previously (Glover, 1970; Hubáček \& Glover, 1970). A Thr- derivative of $\mathrm{HfrH}$ was transduced with PI grown on Escherichia coli with a mutation in the $h s$ gene; from among the $t h r^{+}$transductants 
Table I. Escherichia coli strains employed in the experiments

Strain

$\mathrm{HfrH}$

HfrH-I

HfrH-5K

HfrH-VIII

Hfr JC5088

$\mathrm{C}_{600}$

$\mathrm{C}_{600}-4 \mathrm{~K}$

$\mathrm{C}_{600}-5 \mathrm{~K}$

B25I

C

$4 \mathrm{~K}-29$

IV

VIII

$\mathrm{X}$

XI

IV -28

IV-33

ABI I 57

AB2463

$F^{\prime} X 80 I I$

$F^{\prime}$ KLFI

F'VIII

$\mathrm{F}^{\prime} 5 \mathrm{~K}$

$\mathrm{F}^{\prime} \mathrm{B} 2 \cdot \mathrm{I}$
Host specificity phenotypes

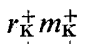

$r_{\mathrm{K}}^{+} m_{\mathrm{K}}^{+}$

$$
\begin{aligned}
& r_{\mathrm{K}}^{-} m_{\mathrm{K}}^{+} \\
& r_{\mathrm{K}}^{-} m_{\mathrm{K}}^{-} \\
& \hline r_{\mathrm{K}}^{+} m_{\mathrm{K}}^{+} \\
& r_{\mathrm{K}}^{-} m_{\mathrm{K}}^{-} \\
& r_{\mathrm{K}}^{-} m_{\mathrm{K}}^{+} \\
& r_{\mathrm{B}}^{+} m_{\mathrm{B}}^{+} \\
& r^{-}-m^{-} \\
& r_{\mathrm{ts}}^{+} m_{\mathrm{ts}}^{+}
\end{aligned}
$$

$r^{-} m^{-}$

$r^{-} m^{-}$

$r^{-} m^{-}$

$r^{-} m^{-}$

$r^{-} m^{-}$

$r^{-} m^{-}$

$r_{\mathrm{K}}^{+} m_{\mathrm{K}}^{+}$

$r_{\mathrm{K}}^{+} m_{\mathrm{K}}^{+}$

$r_{\mathrm{K}} \bar{m} \overline{\mathrm{K}}$

$\mathrm{F}^{\prime} r_{\mathrm{K}}^{+} m_{\mathrm{K}}^{+} / r_{\mathrm{K}}^{+} m_{\mathrm{K}}^{+}$

$\mathrm{F}^{\prime} r_{\mathrm{K}}^{-} m_{\mathrm{K}} / r_{\mathrm{K}}^{+} m_{\mathrm{K}}^{+}$

$\mathrm{F}^{\prime} r_{\mathrm{K}}^{-} m_{\mathrm{K}}^{+} / r_{\mathrm{K}}^{+} m_{\mathrm{K}}^{+}$

$\mathrm{F}^{\prime} r_{\mathrm{B}}^{-} m_{\mathrm{B}}^{+} / r_{\mathrm{K}}^{+} m_{\mathrm{K}}^{+}$
Other characteristics

thi str-s

thr thi str-s

$\left.\begin{array}{l}\text { thi } \text { str-s } \\ \text { thi } \text { str-s }\end{array}\right\}$

ilv thr spc-r str-s rec A56

thr leu thi lac str-s

thr leu serB thi str-r $(\lambda)^{+}$

thr leu thi str-r

try str-s

serB str-s

leu thi str-r $(\lambda)^{+}$

leu thi str-t $(\lambda)^{+}$

leu thi str-r $(\lambda)^{+}$

leu thi str-r $(\lambda)^{+}$

leu thi str-r $(\lambda)^{+}$

leu thi thy str-r $(\lambda)^{+}$

leu thi thy str-r $(\lambda)^{+}$

thr leu arg pro his

thi str-r

thr leu arg pro his

thi rec A13 str-r

$\mathrm{F}^{\prime} l a c^{+} /$lac $\Lambda U \mathrm{I} 69$ str-s

$\mathbf{F}^{\prime} t h r^{+} l e u^{+} / \mathrm{AB} 2463$

$\mathrm{F}^{\prime}$ thr ${ }^{+}$leu $^{+} / \mathrm{AB} 2463$

$\mathrm{F}^{\prime}$ thr ${ }^{+}$leut $/ \mathrm{AB} 2463$.

$\mathrm{F}^{\prime}$ thr $^{+}$leu $^{+} / \mathrm{AB} 2463$
Source or reference

Hayes, 1953

thr mutation introduced by NTG

${ }_{5} \mathrm{~K}$ or VIII mutations were

transduced by PI to HfrH-I

Willetts \& Clark, 1969

Appleyard, 1954

Glover, 1970

Hubáček \& Glover, 1970

Arber \& Dussoix, 1962

Bertani \& Weiglé, 1953

ts mutation I-30 transduced

by Pr to $4 \mathrm{~K}$ (Hubáček \&

Glover, 1970)

By EMS mutagenesis of 4K-29 (Hubáček \& Glover, 1970)

By NTG mutagenesis

By NTG mutagenesis

Howard-Flanders \& Theriot, I966

Hubáček \& Glover, 1970

The construction of the diploids according to Low's technique (Low, 1968)

Hubáček \& Glover, 1970

- , Host specificity phenotype not tested.

HfrH $r_{\overline{\mathrm{K}}} m_{\mathrm{K}}$ (VIII) and $r_{\mathrm{K}} m_{\mathrm{K}}^{+}(5 \mathrm{~K})$ colonies were selected. The partial diploids were constructed by crossing $\mathrm{HfrH}$ strains with $\mathrm{AB} 2463 \mathrm{rec} A$ recipient according to the method described by Low (1968). These merodiploids were used as donors in crosses with appropriate host specificity mutants. The strains were grown in supplemented M9 medium, mated, and $\mathrm{Leu}^{+}$colonies (selected on M9 medium) were purified and their sensitivity to $\mathrm{f} 2$ phage, segregation of $\mathrm{Leu}^{+} / \mathrm{Leu}^{-}$and $\mathrm{m}^{+} / \mathrm{m}^{-}$, and complementation for restriction and modification were followed.

Nitrosoguanidine (NTG) mutagenesis was carried out following the procedure of Adelberg, Mandel \& Chein Ching Chen (1965).

\section{RESULTS}

All the temperature-sensitive mutants described by Hubáček \& Glover (I970) were found to have mutations in the hsm gene. Second-step mutants that had completely lost the capacity to modify at $30^{\circ} \mathrm{C}$ were isolated from strain $4 \mathrm{~K}-29$, carrying mutation $t S I-30$. These were analysed in complementation experiments with the F-prime $\mathrm{F}^{\prime} \mathrm{B} 2$. I $r_{\mathrm{B}}^{-} m_{\mathrm{B}}^{+}$and formed two groups. Mutant strains VIII and X appeared to have both hssK and hsr intact because the diploids expressed both $\mathrm{K}$-specific and B-specific restriction and modification, implying that the second mutation in both parent strains lay in the hsm gene. IV and XI, however, showed only B-specific restriction and modification, suggesting that in these 


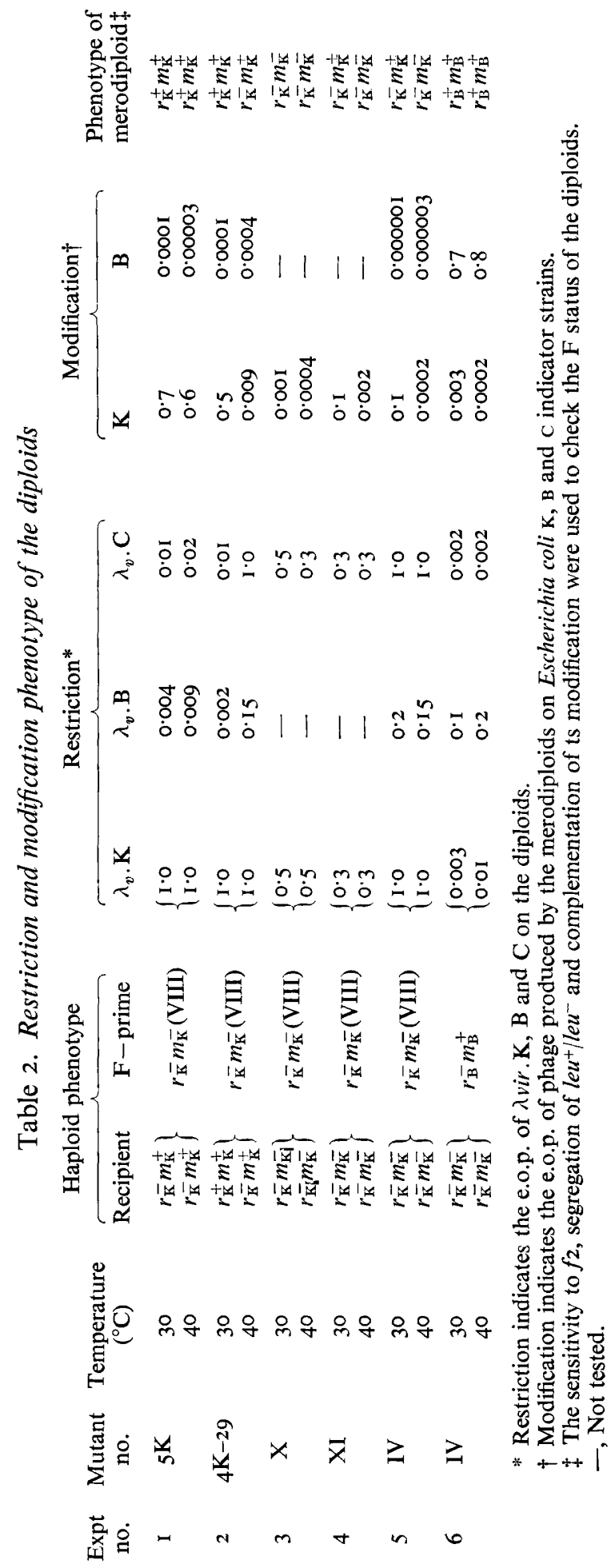


strains the second mutation was in the $h s k$ gene and that the $h s r$ gene was functional because the restriction function missing in the F-prime was efficiently restored (Expt 6 , Table 2).

If the interpretation of these experiments is correct it should be possible to demonstrate complementation between these two types of second-step mutants. An F-prime strain VIII was constructed and used to test for complementation with a number of host specificity mutants. The results of the complementation tests are presented in Table 2. The first three experiments are controls. With $5 \mathrm{~K} r_{\mathrm{K}}^{-} m_{\mathrm{K}}^{+}\left(h s s K^{+} h s r^{-} h s m^{+}\right)$, complementation for $\mathrm{K}$-specific restriction was observed (Expt $\mathrm{I}$ ). If the second mutation in strain VIII is not trans-dominant one would expect temperature-sensitive restriction and modification in the diploid constructed between $\mathrm{F}^{\prime}$ VIII and ${ }_{4} \mathrm{~K}-29 r_{\mathrm{ts}}^{+} m_{\mathrm{ts}}^{+}$recipient and this was actually found (Expt 2 ). The diploid $\mathrm{F}^{\prime} \mathrm{VIII} / \mathrm{F}^{-} \mathrm{X}$ is $r^{-} m^{-}$and no complementation for the restriction and modification was observed as expected for the two second-step mutants of the same genotype (Expt 3).

In the diploids constructed between $F^{\prime}$ VIII and second-step mutant strains IV and XI (Expts 4 and 5) the positive complementation of temperature-sensitive modification confirms the proposed $h s$ genotype of the mutants. However, the level of the modification at $30{ }^{\circ} \mathrm{C}$ is low (only 10 \% of $\lambda$ in the burst is modified) and no complementation for restriction was detectable in the diploids.

Because instability in the diploids may play a role in the observed inefficient complementation, the $\operatorname{rec} A$ mutation was introduced into mutant IV. The donor JC5088 strain with proximal $t h y^{+}$and rec $A 56$ genes was mated with IV-33 thy recipient. A thy ${ }^{+}, \mathrm{UV}^{\mathrm{s}}$ colony (IV-33-5) was isolated which showed about I000-fold lower efficiency of integration when mated with HfrH. The $\operatorname{rec} A$ mutation does not show any marked effect on cell growth in M9 medium; but only about $7 \%$ of cells in the culture form colonies after plating on LA medium. The effect on growth and viability of the cell population was even more pronounced for merodiploids constructed between $\mathrm{F}^{\prime}{ }_{5} \mathrm{~K}, \mathrm{~F}^{\prime} \mathrm{VIII}$ and $\mathrm{F}^{\prime} \mathrm{KLF} \mathrm{I}$ and the recipient IV-33-5 $r e c A$. The cultures not only produce a lower fraction of colony-forming bacteria on LA, but in $\mathrm{M} 9$ medium growth is reduced; as an example, see the $\mathrm{F}^{\prime}{ }_{5} \mathrm{~K} / \mathrm{IV}-33-5$ diploid in Table 3. As a result of this poor growth the strains did not plate $\lambda$ efficiently on LA and M9 agar plates.

Because of these difficulties in using recA derivatives to analyse complementation for temperature-sensitive restriction and modification, the screening technique for isolation of partial diploids was modified. The filamentous growth of the diploids at $40{ }^{\circ} \mathrm{C}$ and the effect of $r e c A$ mutation on their viability suggested that the cells infected with an $\mathrm{F}^{\prime}$ proximal merogenote might be at a selective disadvantage towards $\mathrm{F}^{-}$cells in the culture. To avoid this problem, in further complementation analysis one could attempt to use purified leu $u^{+}$ exconjugants which are $\mathrm{f} 2$ resistant but of the $m^{+}$phenotype at $30^{\circ} \mathrm{C}$. In such bacteria the hs-leu segment is postulated to be either a part of a cryptic plasmid or duplicated in cis and tandem to the original one. Of special interest in this case are cis heterozygous duplications. As shown in Table 4, the expected $\mathrm{f}_{2}{ }^{\mathrm{r}}$ and $m^{+}$phenotype was found among the leu $u^{+}$exconjugants made in this way only with IV-28 thy- recipient (I00 colonies tested); with IV and IV-28 thy ${ }^{+}$spontaneous revertants, among Io colonies tested only f2-sensitive recombinants were detected. The frequency of le $u^{+}$colonies in the cross $\mathrm{F}^{\prime} \mathrm{VIII} \times \mathrm{IV}-28$ thy- is nearly 20-fold lower than in the two other crosses and the f2r, $m^{+}$phenotype among them appears dependent upon thy mutation.

To be sure that these recombinants are completely $\mathrm{F}^{-}$in character, the cultures were mated with ABII57 on M9 agar with supplements to select Leu recombinants (counter- 
Table 3. The growth properties of Escherichia coli strains

\begin{tabular}{|c|c|c|c|c|}
\hline \multirow[b]{2}{*}{ Strain } & \multirow{2}{*}{$\begin{array}{l}\text { Temperature } \\
\text { of } \\
\text { cultivation } \\
\left({ }^{\circ} \mathrm{C}\right)\end{array}$} & \multicolumn{2}{|c|}{ No. of colonies $/ \mathrm{ml}^{*}$ on } & \multirow{2}{*}{$\begin{array}{c}\text { C.f.u. } \dagger \\
\text { on LA } \\
(\%)\end{array}$} \\
\hline & & LA & $\mathrm{M}_{9 \mathrm{~A}}$ & \\
\hline IV -33 & 30 & $3.4 \times 10^{8}$ & $4.0 \times 10^{8}$ & $85 \cdot 0$ \\
\hline IV-33-5 & 30 & $3.2 \times 10^{7}$ & $4.6 \times 10^{8}$ & $6 \cdot 9$ \\
\hline $\mathrm{F}^{\prime}{ }_{5} \mathrm{~K} / \mathrm{IV}-33-5$ & 30 & $1.6 \times 10^{\overline{3}}$ & $5.5 \times 10^{7}$ & 0.2 \\
\hline $\mathrm{F}^{\prime} 5 \mathrm{~K} / \mathrm{IV}-33-5$ & 37 & $2.5 \times 10^{5}$ & $1 \cdot 1 \times 10^{8}$ & 0.2 \\
\hline
\end{tabular}

* No. of colony-forming units after overnight cultivation in M9 medium with appropriate supplements.

$\dagger$ Fraction of cells in the population able to form colonies.

Table 4. The frequency of $f_{2}{ }^{r}, m^{+}$phenotypes among leu ${ }^{+}$ colonies in $F^{\prime} V I I I \times I V$ or $I V-28$ thy $y^{-}$and thy ${ }^{+}$crosses

$\mathrm{F}^{\prime}$ donor strain and the recipients (all strains of $r^{-} m^{-}$phenotype) were grown in supplemented $\mathrm{M} 9$ at $37^{\circ} \mathrm{C}$; thymine concentration $40 \mu \mathrm{g} / \mathrm{ml}$. Equal $0^{\circ} \mathrm{I} \mathrm{ml}$ volumes of the recipient and serial Io-fold dilutions of the donor were mixed and plated on supplemented M9 to select leu $u^{+}$colonies. After purification the sensitivity to $f_{2}$ phage and the modification phenotype were tested.

\begin{tabular}{|c|c|c|c|c|c|c|}
\hline \multirow[b]{2}{*}{ Recipient } & \multirow{2}{*}{$\begin{array}{l}\text { Frequency } \\
\text { of } l e u^{+} \\
\text {colonies* }\end{array}$} & \multirow{2}{*}{$\begin{array}{l}\text { No. of leut } \\
\text { colonies } \\
\text { tested }\end{array}$} & \multicolumn{4}{|c|}{ No. of phenotypes } \\
\hline & & & $\mathrm{f} 2^{\mathrm{s}}, m^{+}$ & $\mathrm{f} 2^{\mathrm{s}}, m^{-}$ & $\mathrm{f} 2^{\mathrm{r}}, m^{+}$ & $\mathbf{f} \mathbf{2}^{\mathbf{r}}, m^{-}$ \\
\hline IV & $8 I \cdot 4$ & Io & 7 & 3 & 0 & 0 \\
\hline IV-28 thy $y^{-}$ & $5 \cdot 0$ & 100 & 7 & I & 60 & 32 \\
\hline IV-28 thy $y^{+}$ & $87 \cdot 8$ & 10 & 9 & I & 0 & 0 \\
\hline
\end{tabular}

Table 5. Restriction and modification in Escherichia coli segregating heterozygotes

The cultures were grown overnight in M9 with thiamine and thymine at the appropriate temperatures and then tested for restriction and modification as described previously (Hubáček \& Glover, I970).

$\begin{array}{cc}\begin{array}{c}\text { Phenotype } \\ \text { no. }\end{array} & \begin{array}{c}\text { Growth } \\ \text { temperature } \\ \left({ }^{\circ} \mathrm{C}\right)\end{array} \\ \text { IV-28 thy } y^{-}-5 & 30 \\ \text { IV-28 thy } y^{-}-1 & 40 \\ & 30 \\ & 40\end{array}$

$\begin{array}{clll}\overbrace{\lambda_{\mathrm{v}} \cdot \mathrm{K}} & \lambda_{\mathrm{v}} \cdot \mathrm{B} & \lambda_{\mathrm{v}} \cdot \mathrm{C} & \begin{array}{c}\text { Modification } \\ (\mathrm{K})\end{array} \\ 0.5 & 0.004 & 0.0 \mathrm{I} & 0.7 \\ 1.0 & 0.3 & 1.0 & 0.02 \\ 0.7 & 0.007 & 0.01 & 0.5 \\ \mathrm{I} \cdot 0 & 0.06 & 0.4 & 0.05\end{array}$

selection against the donor was on agar without thymine) and no such colonies were isolated. In the cross with the Hfr strain $\mathrm{JC}_{5} 088$, which transfers thy as a proximal marker, about $10 \%$ of $t h y^{+}$recombinants per donor were obtained (counter-selection against donor was with streptomycin). The surface exclusion index, measured as the ratio of $t h y^{+}$str-r progeny in $60 \mathrm{~min} I: \mathrm{I}$ crosses with JC5088 as the donor and $\mathrm{F}^{-}$strains IV-28 and the strain in question, was about 2. The $l e u^{+}, \mathrm{f}^{\mathrm{r}}$. recombinants were also mated with an F-lac donor, strain $80 \mathrm{I}$, and $\mathrm{lac}^{+}$thy- $\mathrm{y}^{-}$str-r colonies obtained; a result which again implies that the exconjugants behave as $\mathrm{F}^{-}$.

Complementation for restriction and modification in two such $\mathrm{F}^{-}$recombinants is shown in Table 5. It is evident that this type of recombinant can express complementation of temperature-sensitive restriction and modification of the two second-step mutants VIII and IV.

The $\mathrm{F}^{-}, \mathrm{f}^{\mathrm{r}}$ exconjugants which show complementation were grown in Penassay broth, 


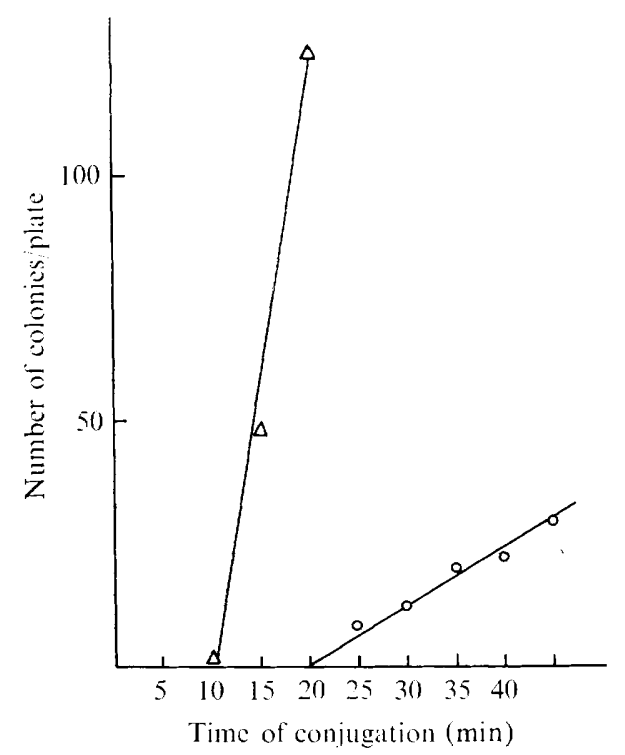

Fig. I. The interrupted mating experiment. The donor IV-28-9, sensitive to nalidixic acid, was grown overnight in M9 with lactose, thiamine and thymine and the recipient, IV, resistant to $20 \mu \mathrm{g} / \mathrm{ml}$ nalidixic acid grown overnight in M9 with glucose, thiamine and leucine were precultivated in Penassay broth $\mathrm{I} 20 \mathrm{~min}$. After I: 10 mixing the bacteria were filtered on Millipore membrane filters; the filters were placed on preheated LA and exposed at $37{ }^{\circ} \mathrm{C}$. At intervals the bacteria were resuspended and the pairs interrupted by agitating in a Vortex mixer. Suspensions were diluted and plated on M9 agar with lactose, thiamine, leucine and nalidixic acid to select lac $^{+}$colonies $(\triangle)$ and M9 agar with glucose, thiamine and nalidixic acid to select $l e u^{+}$colonies (O).

and after dilution the bacteria were plated on $\mathrm{M} 9$ with thiamine, leucine and thymine. After replication on to $\mathrm{Mg}$ agar without leucine and LA agar seeded with Escherichia coli $\mathrm{K}$ and $\mathrm{C}$ soft-agar overlays, the number of $l e u^{-}$and $\mathrm{m}^{-}$segregants was counted. These two markers segregated independently; about $20 \% \mathrm{leu}^{-}$and $10 \% \mathrm{~m}^{-}$colonies were found under these experimental conditions. The phenotype of the $\mathrm{F}^{-}, \mathrm{f}^{\mathrm{r}}$ exconjugant was found to be an unstable $\mathrm{Leu}^{+}$which segregates with the same frequency to $\mathrm{Leu}^{-}$as does stable $\mathrm{Leu}^{+}$. Acriflavine increased the frequency of $\mathrm{Leu}^{-}$colonies up to $60 \%$. To interpret this effect, the sensitivity of the $\mathrm{F}^{-}, \mathrm{f}^{r}$ leu+ colonies and $l e u^{-}$segregants to acriflavine $(5 \mu \mathrm{g} / \mathrm{ml})$ was tested. $\left[{ }^{14} \mathrm{C}\right]$ Uracil incorporation into RNA was measured according to Nakamura \& Suganuma (1972). Uracil incorporation was less sensitive to acriflavine in leu- segregants than in $l e u^{+}$heterozygotes.

The segregating exconjugants were infected with an F-lac ${ }^{+}$episome; about $80 \%$ of $\mathrm{lac}^{+}$ colonies tested were found sensitive to $\mathrm{f} 2$ phage. One $l a c^{+}, \mathrm{f}^{\mathrm{s}}$ colony (IV-28-9) was mated with strain IV as a recipient on $\mathrm{Mg}$ agar without thymine to select against the donor, and $\mathrm{lac}^{+}$ and $l e u^{+}$recombinants were selected. Seventy $\%$ of $\mathrm{lac}^{+}$and $3 \%$ of $l e u^{+}$recombinants/100 donor cells were obtained. The purified recombinants were tested for unselected markers; more than $90 \%$ of $\mathrm{lac}^{+}$colonies were found to be $\mathrm{leu}^{-}$, while $60 \%$ of $\mathrm{leu}^{+}$colonies were also $l a c^{+}$. Only the $l a c^{+}$recombinants were sensitive to f2 phage.

An interrupted mating experiment was performed on membrane filters because of the low frequency of $l e u^{+}$colonies after a 1000 -fold dilution of the mating mixture in Penassay broth. As shown in Fig. I, $\mathrm{lac}^{+}$recombinants appeared at about $10 \mathrm{~min}$ and $\mathrm{leu}^{+}$recombinants at about $20 \mathrm{~min}$ after mixing the donor and recipient bacteria. 


\section{DISCUSSION}

Mutant VIII appears to carry wild-type $h s s K$ because the merodiploid with $\mathrm{F}^{\prime} r_{\mathrm{B}}^{-} m_{\mathrm{B}}^{+}$ expresses K-specific restriction and modification (Hubáček \& Glover, 1970); it has wild-type $h s r$ since it is able to restore by complementation the restriction deficiency in $r_{\mathrm{B}}^{-} m_{\mathrm{B}}^{+}$and $r_{\mathrm{K}}^{-} m_{\mathrm{K}}^{+}$recipients (Table 2 ; Expt I). Both mutations, first-step and second-step, are placed in $h s m$ and we can write the genotype of this mutant as $h s s K^{+} h s r^{+} h s m^{-}$.

On the other hand, mutant IV does not express $\mathrm{K}$-specific restriction and modification in diploids with $\mathrm{F}^{\prime} r_{\mathrm{B}}^{-} m_{\mathrm{B}}^{+}$(Table 2 ; Expt 6), but it appears to have normal wild-type $h s r$ because it complements the restriction deficiencies in $r_{\mathrm{B}}^{-} m_{\mathrm{B}}^{+}$and $r_{\mathrm{K}}^{-} m_{\mathrm{K}}^{+}$mutant strains. We suggest that the genotype of the mutant IV is $h s K^{-} h s r^{+} h s m_{\mathrm{ts}}^{+}$.

From the host specificity genotypes one can expect complementation to produce temperature-sensitive restriction and modification in diploids constructed between $F^{\prime} \mathrm{VIII}$ and mutant IV. The difficulties in the detection of the complementation, especially for restriction, in the diploids were not overcome even in $\mathrm{rec} A$ derivatives of the strain. The filamentous growth, specifically of the diploid cells at $40^{\circ} \mathrm{C}$, and the lower viability of rec $A$ cells infected with $\mathrm{F}^{\prime}$ element, would suggest some selective disadvantage of the $\mathbf{F}^{\prime}$ cells in the bacterial population. The construction of a heterozygous duplication with a tandem arrangement of $h s$ genes was thought to be a way to solve the problem. One might expect such exconjugants to show complementation, to be $\mathrm{F}^{-}$but to segregate $h s$ and leu markers. This type of recombinant was isolated at relatively high frequency using a thy- recipient strain. The role of this mutation in this process as well as the origin of such exconjugants is not clear. Certain mechanisms of prezygotic or postzygotic elimination of the plasmid genes are operating only with the proximal $\mathrm{F}$ merogenote transferred into the recipient strain pre-cultivated in $\mathrm{M} 9$ medium.

The exconjugants were found to be completely $\mathrm{F}^{-}$in character (active as a genetic recipient; lack of activity as a genetic donor; low surface-exclusion index; ability to be infected with $\mathrm{F}$; resistance to male-specific phage), with apparent complementation for restriction and modification; they segregate $h s$ and leu markers. After reinfection with F-lac the diploid behaves like a secondary $\mathrm{F}^{\prime}$ strain transferring lac with high frequency as well as leu which was originally located on the proximal $\mathrm{F}$ merogenote.

Alternatively, one can assume $l e u$ and $h s$ to be attached to a cryptic plasmid; the effect of acriflavine on the segregation of the leu marker is compatible with this interpretation. However, the higher sensitivity of RNA synthesis to acriflavine in the diploids weakens this argument. The leu- segregants could grow faster under these conditions and thus predominate in the population. It is possible that two genetically different variants of the same plasmid can exist more or less stably in the same cell despite the incompatibility barrier which normally prevents this situation.

Positive results in complementation of temperature-sensitive restriction and modification has revealed that the genotypes of the two groups of mutants deficient in both restriction and modification are as we have proposed (Hubáček \& Glover, 1970). One mutant is impaired in the specificity gene while the other is mutated in the hsm gene, and both have an intact $h s r$ gene. It is evident that a mutation in $h s m$ can express the same phenotypic effect on restriction and modification as the impaired hss gene and that for restriction the interaction of $h s s, h s r$ and $h s m$ gene products is required. Studies of the sub-unit structure of the restriction endonuclease from Escherichia coli B by Eskin \& Linn (1972) are entirely consistent with this model. 
I acknowledge the valuable suggestions and comments of Professor S. W. Glover during preparation of the manuscript. I also wish to thank Miss Věra Myšková for technical assistance.

\section{REFERENCES}

Adelberg, E. A., Mandel, M. \& Chein Ching Chen, G. (1965). Optimal conditions for mutagenesis by $N$-methyl- $N^{\prime}$-nitro- $N$-nitrosoguanidine in Escherichia coli K-12. Biochemical and Biophysical Research Communications 18, 788--795.

APPLEYARD, R. K. (1954). Segregation of new lysogenic types during growth of a doubly lysogenic strain derived from Escherichia coli K-I2. Genetics 39, 440-452.

ARber, W. \& DussoIx, D. (1962). Host specificity of DNA produced by Escherichia coli. I. Host controlled modification of bacteriophage $\lambda$. Journal of Molecular Biology 5, 18-36.

ARber, W. \& LinN, S. (1969). DNA modification and restriction. Annual Reviews of Biochemistry 38, 467-500.

BeRTANI, G. \& WeIGlÉ, J. J. (1953). Host controlled variation in bacterial viruses. Journal of Bacteriology 65, II3-12I.

Eskin, B. \& LINN, S. (1972). The deoxyribonucleic acid modification and restriction enzymes of Escherichia coli в. II. Purification, subunit structure, and catalytic properties of the restriction endonuclease, Journal of Biological Chemistry 247, 6183-6191.

GLOVER, S. W. (1970). Functional analysis of host-specificity mutants in Escherichia coli. Genetical Research I5, 237-250.

GLOVER, S. W. \& COLSON, C. (1969). Genetics of host-controlled restriction and modification in Escherichia coli. Genetical Research r3, 227-240.

HAYES, W. (1953). The mechanism of genetic recombination in Escherichia coli. Cold Spring Harbor Symposium Quantitative Biology 18, 75-93.

Howard-Flanders, P. \& Theriot, L. (I966). Mutations of Escherichia coli $\mathrm{K} 12$ defective in DNA repair and genetic recombination. Genetics 53, II 37-1 150.

HubÁČEK, J. \& Glover, S. W. (I970). Complementation analysis of temperature-sensitive host specificity mutations in Escherichia coli. Journal of Molecular Biology 50, 1 I I-127.

Low, B. (1968). Formation of merodiploids in matings with a class of $\mathrm{rec}^{-}$recipient strains of Escherichia coli $\mathrm{K}$ 12. Proceedings of the National Academy of Sciences of the United States of America 60, 160-167.

Nakamura, H. \& Suganuma, A. (1972). Membrane mutation associated with sensitivity to acriflavine in Escherichia coli. Journal of Bacteriology 110, 329-335.

WilletTs, N. S. \& CLARK, A. J. (1969). Characteristics of some multiply recombination-deficient strains of Escherichia coli. Journal of Bacteriology 100, 23I-239. 